\title{
Postmenopause and metabolic syndrome
}

\author{
Sena Sayan ${ }^{1^{\star}}$ and Recep Yıldızhan ${ }^{2}$ \\ ${ }^{1}$ Saglik Bilimleri University, Van Training and Research Hospital, Department of Obstetrics and Gynecology, Van, Turkey \\ ${ }^{2} V$ an Yuzuncu Yil University, School of Medicine, Department of Obstetrics and Gynecology, Van, Turkey
}

\begin{abstract}
In this review, the causes and results of the metabolic syndrome and the relationship between vasomotor symptoms like hot flashes, night sweats, which started with the termination of ovarian activity in the postmenopausal period, were compared.

The pathophysiology of the postmenopausal and metabolic syndrome has been examined in parallel. Vasomotor symptoms have been shown to be more severe in postmenopausal women with metabolic syndrome.
\end{abstract}

Key Words: Postmenopause, metabolic syndrome, vasomotor symptoms

\section{Introduction}

The postmenopausal period begins twelve months after the last menstruation. Despite being a physiological process, menopause-specific conditions put postmenopausal women in a delicate group. Menopause complication affects the quality of life. With the improvement in life expectancy and medicine, the elderly population is increasing especially in the developed countries. Thus, the number of women entering the menopause increased but the mean menopause age did not change (1). With the loss of function of the ovaries and a decrease in estrogen levels, it causes many symptoms that adversely affect quality of life, as hot flashes, mood swings, night sweats and irregular sleep patterns. Estrogen deficiency can lead to long-term lifethreatening conditions like cardiovascular disease and osteoporosis. The incidence of vasomotor symptom at the level that would impair the quality of life in post-menopausal women is $60-80 \%$ (2). Metabolic syndrome is a metabolic disorder with increased risk of cardiovascular disease in which factors like dyslipidemia, abdominal fat accumulation, obesity, impaired glucose tolerance, insulin resistance, DM, and hypertension are clustered (3). The International Diabetes Federation (IDF) and the American Heart Association / National Heart Lung Blood Institute (AHA / NHLBI) have reached consensus on the description of metabolic syndrome (Table 1) (4). In a postmenopausal woman with metabolic syndrome, the conversion of adrenal steroid to estrogen in the abdominal fat tissue is the reason that FSH value is low and the estradiol value is high. (5). Therefore, when the testosterone aromatization to estrogen in the fatty tissue of the body considered, multifactorial vasomotor symptoms may be less likely to occur in patients with metabolic syndrome (6). While postmenopausal women have decreased HDL levels compared to premenopausal women, total cholesterol, LDL, triglyceride levels and cardiovascular disease risk have increased (7). Metabolic syndrome prevalence increases with menopause (2). Jeenduang et al. (8) Have shown an increased prevalence of metabolic syndrome in postmenopausal women and reported that the prevalence was between $16 \%$ and $69 \%$ in different populations. The increased risk of cardiovascular disease with menopause is further increased by the metabolic syndrome (9). The prevalence of metabolic syndrome is reported to be $22 \%$ in adults. Prevalence increases with age, $6.7 \%$ in 20-29 age group and $43.5 \%$ in 60-69 age group (3). According to TEKHARF study, by 2000, 9.2 million people aged 30 years and over have metabolic syndrome, and 53\% of people with cardiovascular disease also have metabolic syndrome (7). Our country has high prevalence of metabolic syndrome, $28 \%$ in males and $40 \%$ in females (10).

No genetic, infectious, or environmental factors have been found that may clarify the pathogenesis of all components of the metabolic syndrome. Metabolic syndrome is a heterogeneous endocrinopathy that develops on the basis of insulin resistance. Although polygenic susceptibility is a matter of concern, the sedentary lifestyle of modern urban life and high calorie diet exacerbate the course of this syndrome (11). Insulin resistance is biologically unresponsiveness to insulin. Genetic factors, fetal malnutrition, physical inactivity, obesity and age 
Table 1. Consensus (UDF+AHA/NHLBI) 2009 (4)

Three of the following diagnosed as metabolic syndrome

\begin{tabular}{l}
\hline Increased waist circumference BMI $>30 \mathrm{~kg} / \mathrm{m}^{2}$ \\
\hline $\mathrm{TG} \geq 150 \mathrm{mg} / \mathrm{dl}$ \\
\hline HDL $<40($ male $),<50($ female $)$ \\
\hline Blood pressure $\geq 130 / 85 \mathrm{~mm} / \mathrm{hg}$ \\
\hline Fasting Blood Glucose $\geq 100 \mathrm{mg} / \mathrm{dl}$ \\
\hline
\end{tabular}

progression are common causes. Due to this resistance, hyperinsulinemia develops in order to keep blood glucose at normal level. In practice, HOMA (fasting insulin $(\mu \mathrm{u} / \mathrm{ml}) \mathrm{x}$ fasting plasma glucose $(\mathrm{mg}$ / dl) / 405) score is lower than 2.7 in normal individuals; Above 2.7, it reflects insulin resistance at different grades $(12,13)$. It's not necessary that all type $2 \mathrm{DM}$ patients have insulin resistance. However, if the patient has significant Diabetes Mellitus and impaired glucose tolerance is considered insulin resistance for diagnosis. The diagnosis of diabetes mellitus is based on fasting plasma glucose and oral glucose tolerance test (OGTT) values (Tables 2 and 3). The risk of developing type $2 \mathrm{DM}$ in patients with metabolic syndrome is 5 times higher than healty individuals (14). Thus, the risk of developing type $2 \mathrm{DM}$ in the presence of both insulin resistance and metabolic syndrome is 6-7 times higher than in other people (15).

One of the causes of essential hypertension is insulin resistance (13). Insulin; Stimulates renal water and salt uptake by enhancing central sympathetic activity and it balances the effect on blood pressure by creating

Table 2. Classification of fasting plasma glucose levels (16).

\begin{tabular}{ll}
\hline $\begin{array}{l}\text { Fasting plasma } \\
\text { glucose level }\end{array}$ & Definition \\
\hline$<100 \mathrm{mg} / \mathrm{dl}$ & Normal \\
\hline $100-125 \mathrm{mg} / \mathrm{dl}$ & Impaired fasting glucose \\
\hline$\geq 126 \mathrm{mg} / \mathrm{dl}$ & Diabetes mellitus \\
\hline
\end{tabular}

Table 3. Classification of 2. Hour OGTT (75g) plasma glucose levels (16)

\begin{tabular}{ll}
\hline $\begin{array}{l}\text { 2. hour plasma glucose } \\
\text { level }(75 \mathrm{~g} \text { OGTT) }\end{array}$ & Definition \\
\hline$<140 \mathrm{mg} / \mathrm{dl}$ & Normal \\
\hline $140-199 \mathrm{mg} / \mathrm{dl}$ & $\begin{array}{l}\text { Impaired glucose } \\
\text { tolerance }\end{array}$ \\
\hline$\geq 200 \mathrm{mg} / \mathrm{dl}$ & Diabetes mellitus \\
\hline
\end{tabular}

peripheral vasodilatation. In the presence of insulin resistance, hypertension is caused by resistance to the effect of peripheral vasodilators (17). Hypertension in patients with metabolic syndrome is associated with high levels of resistin and low levels of adiponectin (18). The endothelium is an active endocrine organ that produces vasodilators (nitric oxide) and vasoconstrictors (angiotensin II) that balance each other under normal conditions. The loss of balance between these two effects on the endothelium is referred to as endothelial dysfunction $(13,17)$. In the postmenopausal period, vascular endothelial dysfunction (deterioration of vascular tone regulatory function) and atherosclerosis associated with decreased estrogen develops cardiac artery diseases. Metabolic syndrome is accepted as a risk factor for early-onset atherosclerosis (17). Patients have a 2-3 times higher mortality risk associated with cardiovascular disease (24). Another study showed a 1.5-fold increase in stroke risk in patients with metabolic syndrome (25). In metabolic syndrome, triglycerides and VLDL are increased, HDL is low, but LDL is not usually elevated. As insulin resistance progresses, triglyceride levels increase and HDL levels decrease. Hypertriglyceridemia and low HDL increase cardiovascular disease risk (19). Abdominal obesity and low HDL increases the prevalence of metabolic syndrome in postmenopausal women (20).

Although abdominal obesity is the most important indicator of insulin resistance, some of the cases of insulin resistant metabolic syndrome may not have obesity. Adipose tissue is an active endocrine organ that secretes cytokines (TNF-a, IL-6, IL-8) and many hormones such as leptin, resistin, adiponectin (13). Approximately $50 \%$ of postmenopausal women have been shown to be obese (21). In postmenopausal period even though there is no weight gain, redistribution increases central obesity which can trigger metabolic syndrome. Gluteofemoral fat accumulation is decreased and metabolic active abdominal fat accumulation is increased (22). Abdominal obesity has been suggested to contribute to insulin resistance and to cause dyslipidemia, glucose intolerance and hypertension (23). Insulin resistance is followed by hepatosteatosis, steatohepatitis and even cirrhosis (19). Patients with metabolic syndrome are 4 to 11 times more likely to develop non-alcoholic fatty liver in the future. Insulin resistance is the key pathologic factor in both cases (26). Non-alcoholic fatty liver is strongly associated with cardiovascular disease (27). The prevalence in the general population is estimated around $20-30 \%$. (28). Insulin resistance may result in chronic anovulation and infertility with hyperandrogenism (29). Metabolic syndrome is associated with 
hypogonadism in both men and women. Hypogonadism is also a risk factor for metabolic syndrome and type 2 DM. Hormone Replacement Therapy (HRT) improves the characteristics of the metabolic syndrome for both sexes (30). In patients with metabolic syndrome, obesity is strongly associated with osteoarthritis and gut disease in the knees (31). Evidence suggests that the development or progression of colorectal, prostate, and breast cancers is due to obesity in patients with metabolic syndrome $(32,33)$. Type $2 \mathrm{DM}$ is also associated with increased risk of developing cancer (34). In the prevention of vasomotor symptoms in the postmenopausal period, as HRT is currently inadequately used and there is no effective treatment to relieve these symptoms, it seems to be the right way to find and remove symptoms that exacerbate the symptoms (35). Metabolic syndrome prophylaxis is provided with regular exercise and appropriate dietary habits in postmenopausal women. Organized, groupbased exercise, followed by home training and selfguided physical activity, reduces cardiovascular disease risk, which continuously improves cardiometabolic parameters.

\section{References}

1. Grady D. Clinical practice. Management of menopausal symptoms. N Engl J Med 2006; 355: 2338-2347.

2. Reid R, Abramson BL, Blake J, Desindes S, Dodin S, Johnston S, et al. Managing menopause. J Obstet Gynaecol Can 2014; 36: 830-838.

3. Ford ES, Giles WH, Dietz WH. Prevalence of the metabolic syndrome among US adults: findings from the third National Health and Nutrition Examination Survey. JAMA 2002; 287: 356-359.

4. Alberti KG, Eckel RH, Grundy SM, Zimmet PZ, Cleeman JI, Donato KA, et al. Harmonizing the metabolic syndrome: a joint interim statement of the International Diabetes Federation Task Force on Epidemiology and Prevention; National Heart, Lung, and Blood Institute; American Heart Association; World Heart Federation; International Atherosclerosis Society; and International Association for the Study of Obesity. Circulation 2009; 120: 1640-1645.

5. Malacara JM, Fajardo ME, Nava LE. Gonadotropins at menopause: the influence of obesity, insulin resistance, and estrogens. Steroids 2001; 66: 559-567.

6. Campagnoli C, Morra G, Belforte P, Belforte L, Prelato Tousijn L. Climacteric symptoms according to body weight in women of different socioeconomic groups. Maturitas 1981; 3: 279-287.

7. Stevenson JC, Crook D, Godsland IF. Influence of age and menopause on serum lipids and lipoproteins in healthy women. Atherosclerosis 1993; 98: 83-90.
8. Jeenduang N, Trongsakul R, Inhongsa P, Chaidach P. The prevalence of metabolic syndrome in premenopausal and postmenopausal women in Southern Thailand. Gynecol Endocrinol 2014; 30: 573-576.

9. Effects of estrogen or estrogen/progestin regimens on heart disease risk factors in postmenopausal women. The Postmenopausal Estrogen/Progestin Interventions (PEPI) Trial. The Writing Group for the PEPI trial. JAMA 1995; 273: 199-208.

10. Kozan O, Oguz A, Abaci A, Erol C, Ongen Z, Temizhan A, et al. Prevalence of the metabolic syndrome among Turkish adults. Eur J Clin Nutr 2007; 61: 548-553.

11. Dalvand S, Niksima SH, Meshkani R, Ghanei Gheshlagh R, Sadegh-Nejadi S, Kooti W, et al. Prevalence of Metabolic Syndrome among Iranian Population: A Systematic Review and Meta-analysis. Iran J Public Health 2017; 46: 456-467.

12. Expert Panel on Detection E, Treatment of High Blood Cholesterol in A. Executive Summary of The Third Report of The National Cholesterol Education Program (NCEP) Expert Panel on Detection, Evaluation, And Treatment of High Blood Cholesterol In Adults (Adult Treatment Panel III). JAMA 2001; 285: 2486-2497.

13. Pyorala M, Miettinen $\mathrm{H}$, Halonen P, Laakso M, Pyorala K. Insulin resistance syndrome predicts the risk of coronary heart disease and stroke in healthy middle-aged men: the 22-year follow-up results of the Helsinki Policemen Study. Arterioscler Thromb Vasc Biol 2000; 20: 538-544.

14. Ford ES, Li C, Sattar N. Metabolic syndrome and incident diabetes: current state of the evidence. Diabetes Care 2008; 31: 1898-1904.

15. Meigs JB, Rutter MK, Sullivan LM, Fox CS, D'Agostino RB, Sr. Wilson PW. Impact of insulin resistance on risk of type 2 diabetes and cardiovascular disease in people with metabolic syndrome. Diabetes Care 2007; 30: 1219-1225.

16. American Diabetes A. Diagnosis and classification of diabetes mellitus. Diabetes Care 2004; 27 Suppl 1: 5 10.

17. Onat A, Ceyhan K, Basar O, Erer B, Toprak S, Sansoy V. Metabolic syndrome: major impact on coronary risk in a population with low cholesterol levels--a prospective and cross-sectional evaluation. Atherosclerosis 2002; 165: 285-292.

18. Papadopoulos DP, Perrea D, Thomopoulos C, Sanidas E, Daskalaki M, Papazachou U, et al. Masked hypertension and atherogenesis: the impact on adiponectin and resistin plasma levels. J Clin Hypertens (Greenwich) 2009; 11: 61-65.

19. Bersot TP, Vega GL, Grundy SM, Palaoglu KE, Atagunduz P, Ozbayrakci S, et al. Elevated hepatic lipase activity and low levels of high density lipoprotein in a normotriglyceridemic, nonobese Turkish population. J Lipid Res 1999; 40: 432-438. 
20. Adams-Campbell LL, Dash C, Kim BH, Hicks J, Makambi K, Hagberg J. Cardiorespiratory Fitness and Metabolic Syndrome in Postmenopausal AfricanAmerican Women. Int J Sports Med 2016; 37: 261 266.

21. Da Silva HG, Mendonca LM, Conceicao FL, Zahar SE, Farias ML. Influence of obesity on bone density in postmenopausal women. Arq Bras Endocrinol Metabol 2007; 51: 943-949.

22. Sowers MF, Zheng H, Tomey K, Karvonen Gutierrez C, Jannausch M, Li X, et al. Changes in body composition in women over six years at midlife: ovarian and chronological aging. J Clin Endocrinol Metab 2007; 92: 895-901.

23. Dandona P, Aljada A, Chaudhuri A, Mohanty P, Garg R. Metabolic syndrome: a comprehensive perspective based on interactions between obesity, diabetes and inflammation. Circulation 2005; 111: 1448-1454

24. Lakka HM, Laaksonen DE, Lakka TA, Niskanen LK, Kumpusalo E, Tuomilehto J, et al. The metabolic syndrome and total and cardiovascular disease mortality in middle-aged men. JAMA 2002; 288 : 2709-2716.

25. Boden-Albala B, Sacco RL, Lee HS, Grahame-Clarke C, Rundek T, Elkind MV, et al. Metabolic syndrome and ischemic stroke risk: Northern Manhattan Study Stroke 2008; 39: 30-35.

26. Hamaguchi M, Kojima T, Takeda N, Nakagawa T, Taniguchi H, Fujii K, et al. The metabolic syndrome as a predictor of nonalcoholic fatty liver disease. Ann Intern Med 2005; 143: 722-728.

27. Volzke H, Robinson DM, Kleine V, Deutscher R, Hoffmann W, Ludemann J, et al. Hepatic steatosis is associated with an increased risk of carotid atherosclerosis. World J Gastroenterol 2005; 11: 1848-1853.

28. Bedogni G, Miglioli L, Masutti F, Tiribelli C, Marchesini G, Bellentani S. Prevalence of and risk factors for nonalcoholic fatty liver disease: the Dionysos nutrition and liver study. Hepatology 2005; 42: 44-52.

29. Madani T, Hosseini R, Ramezanali F, Khalili G, Jahangiri N, Ahmadi J, et al. Metabolic syndrome in infertile women with polycystic ovarian syndrome. Arch Endocrinol Metab 2016, 60: 199-204.

30. Cornier MA, Dabelea D, Hernandez TL, Lindstrom RC, Steig AJ, Stob NR, et al. The metabolic syndrome. Endocr Rev 2008; 29: 777-822.

31. Magliano M. Obesity and arthritis. Menopause Int 2008; 14: 149-154.

32. Ahmed RL, Schmitz KH, Anderson KE, Rosamond WD, Folsom AR. The metabolic syndrome and risk of incident colorectal cancer. Cancer 2006; 107: 28 36.

33. Pasanisi P, Berrino F, De Petris M, Venturelli E, Mastroianni A, Panico S. Metabolic syndrome as a prognostic factor for breast cancer recurrences. Int J Cancer 2006; 119: 236-238.

34. Inoue M, Iwasaki M, Otani T, Sasazuki S, Noda M, Tsugane S. Diabetes mellitus and the risk of cancer: results from a large-scale population-based cohort study in Japan. Arch Intern Med 2006; 166: 1871 1877.

35. Mazurek K, Żmijewski P, Kozdroń E, Fojt A, Czajkowska A, Szczypiorski P, et al. Cardiovascular risk reduction in sedentary postmenopausal women during organised physical activity. Kardiol Pol 2017; 75: 476-485. 